\title{
A Study Showing Research has been Valued over Teaching in Higher Education
}

\section{Chi Yuan Chen ${ }^{1}$}

Abstract: Research has been valued and given priority over teaching for a long time in academia. In recent decades, the Taiwanese Ministry of Education has pursued objective and quantitative research criteria and has encouraged higher education institutions to ask teachers to publish papers in SSCI or SCI journals as part of the criteria for promotion and evaluation. This policy strengthens the concept that research has priority over teaching because teachers must devote more time to research than to teaching in order to be promoted and evaluated. The purpose of this study is to explore the influences that cause teachers to value research over teaching. To achieve this purpose, document analysis, the analysis of Taiwan Higher Education database and interviews were adapted as methods. First of all, our researchers collected and analyzed the documents for promotion and evaluation of twelve different universities whose areas of specialty included general studies, education, medicine, vocational studies, and the arts. Then, the study used and analyzed the empirical data of teachers' working hours every week for different tasks from the Taiwan Higher Education Database which investigated the working conditions of teachers in higher education in 2004. Additionally, twenty professors who have different areas of study and work in different types of universities were interviewed to collect teachers' opinions of the task priority of research, teaching, and service duties. The results showed that academia in Taiwan exhibits the phenomenon that research is valued over teaching. The reasons are due to the requirements of the reward system. The reward system emphasizes research over teaching and service. Teachers' research achievements are judged based on publishing articles in different types of journals and the amount of research funding they can obtain. The results also showed that every week teachers spend the most time on teaching, then on research, and finally on service. However, teachers emphasize research as the most important task, then teaching, and finally service. Although the majority of teachers think research is the most important duty, there is still twenty percent of teachers who think it is the least important. Although teaching has been thought of as the second most important duty after research, it is the task that the most teachers give as the first priority as far as time spent and none of the interviewees thought it is the least important. Universities and teachers all try to use their professionalism as capital to gain financial support from the government. This situation forces teachers to try to put more time and energy into research, but they still need to maintain teaching and service work quality. Some teachers focus more time and energy on research and ignore the needs of students. Working time endlessly increases even for teachers who out value on both teaching and research. Some suggestions based on the findings have been proposed for Taiwanese higher institutions.

\footnotetext{
${ }^{1}$ Chinese Culture University, cqy8@ faculty.pccu.edu.tw
} 
Keywords: research, teaching, promotion, tenure, higher education, professoriate

\section{Introduction}

The duties of teachers in higher education include teaching, research, and administrative service. Besides delivering knowledge, professors need to do research and provide service to produce and share professional knowledge. They need to produce products of their research, connect the research results to teaching, and offer professional service to society. These duties are the way in which teachers of higher education, secondary education, and elementary education differ (Du, 2002; Sun, 2007; Wei \& Cheng, 2006; Wu, 2007).

The importance among professors' three primary duties is not equal. Early research has found that among these three duties, the first priority is research, then teaching, and finally service (Commonwealth, 2012; Du, 2002; Dunkin, 1994; Euster \& Weinbach, 1983, 1994; Gibbs \& Locke, 1989; Green, 2008; Parker, 2008; Wei \& Cheng, 2006; Vardi \& Quin, 2011). One of the reasons for this situation is that the reward system for teachers in higher education is always based on the products of research (Knapper, 1997; Fairweather, 1992; Walker, Baepler, \& Cohen, 2008). Although the promotion and teacher evaluation criteria emphasize research products, interestingly, early research found that teachers spend more time on teaching and service than on research. The tasks of teaching and service form the pressure and challenge of teachers' everyday work. Research is usually only done during a professor's leisure time after finishing mandatory teaching and service (Commonwealth, 2012; Seaberg, 1998; Seipel, 2003). The current study aims to explore whether the phenomenon that research has been valued over teaching exists in Taiwan's academia, and the reasons causing and influencing this phenomenon.

\section{Literature Review}

\section{The priority between research and teaching}

Early research which focused on the priority of teaching and research found that the priority of teaching was higher than that of research (Miller, 1978; Euster \& Weinbach, 1983). In the process of the evolution of the function of higher education, teaching was the very first purpose, and then several famous universities began to initiate the function of research. Finally, the function of research spread, was emphasized, and was institutionalized (Du, 2002). There are many reasons why higher education emphasizes research over teaching. One is that some teachers think teaching cannot bring them recognition and value. The teacher who posits him or herself as a researcher gets more funding from outside sources, more opportunities to be an advisor, more opportunities for rewards, and is more satisfied with his/her job (Fox, 1985). Dunkin (1994) suggests four reasons why higher education puts lower recognition on teaching. First, the reputation of an outstanding teacher is rarely known outside his/her school. Second, compared to the products of research, the products of teaching are hard to measure and quantify. Third, the definition of effective teaching is different among higher education institutions, but the standard of outstanding research is in common practice internationally. Fourth, the technology of chemistry and business products depend more on research and the higher education institutions which have offered research since World War II. Therefore, the role of teaching has declined. Another reason is that the government gives university funding based more on the evaluation of research products than the quality of teaching activities, as pointed out by Young (2006). 
In Taiwan, the situation that higher education emphasizes research over teaching may be because the teaching hours of teachers in higher education are arranged based on teachers' rank. The higher the teacher's rank, the fewer teaching hours the teacher has. The original intention of this rule was to lighten the teaching load of higher ranking teachers to give them more time to do research, but unexpectedly formed the image that teaching is not as important as research (Chen, 2001). Moreover, the Ministry of Education's pursuit of the objective quantification data of research products pushed universities to use the promotion and evaluation system to force teachers put more time and energy on research (Chou, $\mathrm{Wu}, \& \mathrm{Hu}, 2011)$. Additionally, the opinion that better performing public Taiwanese universities support research and private Taiwanese universities that emphasize teaching have lower reputations than public schools also strengthens the value that research is better than teaching ( $\mathrm{Du}, 2002)$. Lastly, the products of research are easy to quantify, but teaching is too subjective to measure quantitatively. Teachers would rather ignore teaching quality and do research in order to pass the promotion and evaluation criteria.

Research about the priority between research and teaching can be categorized into three categories. The first one explores how teachers weigh different duties by collecting teachers' opinions and/or analyzing the criteria of promotion and evaluation system. The second one explores how teachers arrange their working time by investigating the time teachers spend on different duties or their workloads to understand the importance of different duties. The third one explores the influence of the university reward system on the working preference of teachers.

\section{Collecting teachers' opinions or analyzing the criteria of promotion and evaluation system}

In the early 1970s, Miller (1978) invited fifty-four deans and directors of universities as interview samples to investigate promotion requirements. The result showed that fifty directors (92.5\%) of the fifty-four samples thought teaching effectiveness was the most important criteria for teacher recruitment, promotion, and evaluation. The importance of research was only higher than community service. Since this study, Euster and Weinbach have twice done investigations, one in 1981 with fifty-four deans and the other in 1992 with ninety-two directors of universities as samples for each. They asked the testers to rank the order of importance among the five duties of teaching, publication, research, grants or contracts, and community service. The results showed that publication had replaced teaching and had become the most important criterion for promotion and tenure. The result of the 1981 study showed that teaching was the most important criterion and research was the second most important, but the result of the 1992 study showed that teaching had declined to the second place and research had become the first priority. Service was always in the third place and not the teacher's primary working role (Euster \& Weinbach, 1983; 1994). Gibbs and Locke (1989) interviewed ninety-two professors and got similar results to the two studies mentioned above. They found that research and academic publications were the most important criteria for promotion and tenure decisions. Teaching was the second most important criterion and service was the third. The Higher Education Academy in the United Kingdom asked 2,700 university professors about their feelings on teaching, research, and service in 2009. The results showed that all the professors thought teaching and learning were very important but not emphasized equally. They also explored the promotion criteria of higher education institutions and found that the promotion criteria of teaching are not consistent, are absent, or are mentioned in the rules but not carried out practically. In 104 universities, every university showed research promotion criteria, and in only seventy-three universities the promotion policies included teaching and learning activities. In these seventy-three universities, only forty-five universities (61.6\%) had 
clear teaching evaluation criteria. In research-intense universities, only $58 \%$ had teaching promotion criteria. These results reflected the professors' perceptions that teaching is not recognized in the process of promotion decision (The Higher Education Academy, 2009).

Dunkin (1991) found that research products seem to have more influence in promotion than teaching, but the difference between them may not be as large as expected. The importance of teaching and research in universities is changing but the direction in which they are changing is not predetermined. Some universities emphasize teaching more, some universities emphasize research more, and some universities emphasize both equally. After the research study in 1991, Dunkin (1994) hypothesized that teachers who got teaching awards may have different opinions about the relationship between teaching and research. He invited twelve teaching award winners as interviewees and found that these teachers love teaching more than research. One teacher thought teaching leads to research, four teachers thought teaching depends on research, five teachers thought teaching and research interact with each other, and two teachers thought teaching and research were independent of each other. Green (2008) used an internet questionnaire as an investigation method and asked 154 university department directors to offer information about their college or department. One hundred and thirty people (84.3\%) answered his questionnaire. The results had similar findings to previous research, showing that research has become the most important criterion in the $21^{\text {st }}$ century, and teaching and research are not as important and have a more minor influence. Despite most universities viewing research as the most important criterion, there still are some universities that put teaching in the most important position or view teaching, research, and service as having equal importance. Unlike other studies which used teaching opinion investigation as methodology, Parker (2008) tried to analyze the promotion criteria of universities. He categorized promotion criteria and their percentages and tried to analyze the fairness of teaching and research evidence recognition. The results showed that the arrangement of teaching and research promotion criteria for senior and principal lecturers is more equal. The promotion criteria for higher ranking and more reputable senior lecturers and professors require outstanding research products in most universities, and these teachers cannot apply for promotion based on teaching activities. Parker (2008) also found that the universities which were established after 1992 are clearly more supportive of teaching than traditional universities which were established before 1992 and tend to recognize teaching and research more equally.

In Taiwan, Du (2002) asked professors to assess the level to which their universities emphasize teaching and research. The result showed that public universities emphasize teachers' research tasks more than private universities, and private universities emphasize teaching tasks more than public universities. The promotion criteria of universities in Taiwan focus on research and even try to eliminate teachers who have weak research performance through research accountability evaluations. To pursue outstanding academics, the research-intense universities' research expectations of their teachers are transformed from a promotion award into formal work requirements. Teachers have no freedom to choose to do research work anymore, so doing research has become professors' primary duty (Du, 2002). Lin and Yang (2011) found that although the criteria of teacher evaluation is divided into teaching, research, and service, what has the most influence is publication and research projects. Commonwealth Magazine launched an investigation in 2012 and found that $86 \%$ of teachers thought the teacher evaluation criteria they face emphasizes research more than teaching (Commonwealth, 2012). Wei and Cheng (2006) used a questionnaire to investigate 1,528 students from universities and colleges. They tried to explore students' emphasis of teachers' abilities in research, teaching and service. The result found that students emphasize teachers' teaching ability more than their research abilities. Students have different 
attitudes towards teachers' abilities in research, teaching, and service based on many student factors, such as gender, grade, score, major, and life plan.

\section{Investigating the time teachers spend on different duties or their workload to understand the importance of different duties}

Seaberg (1998) used the amount of time teachers spend on their work to explore the importance of teaching and research. He found that $65 \%$ of teachers who work in graduate school pointed out that the time they spend on teaching and service is longer than on research. The time spent on research comes last and it is usually additional work besides teaching and service. Seipel (2003) also found teaching and service were the main roles of professors and research work was ranked third. If research performance has definite rewards, research and publication will eventually outrank teaching importance. Teaching and attending meetings are the source of pressure and challenge for everyday work. Du (2002) found that on average, every teacher spends half of their working time on teaching tasks and about $40 \%$ of their working time on research tasks. Higher ranking teachers are more interested in and have more achievements in their research tasks, so they spend more time on research work and less time on teaching work. Teachers of different rank spend different amounts of time on each task. Professors spend the most time on research and lecturers spend less time on research. In the beginning of teachers' careers (1-5 years), teachers are in the stage of teaching involvement and teachers who are senior (6-10 years) are in the peak stage of research. About $40 \%$ of teachers belong to the teaching orientation, about $15 \%$ of teachers belong to the research orientation, and about $45 \%$ of teachers belong to both teaching-and-research orientation. Commonwealth magazine (2012) found that $47 \%$ of professors spend more time on teaching than on research $(34 \%)$ and on service $(17 \%)$.

\section{Exploring the influence of the university reward system to the working preference of teachers}

We can try to understand the required job tasks of professors from the regulation of recruitment, tenure, promotion, and dismissal. The university reward system reflects the key works of professors. Although professors think teaching and research should have similar weight in the system of promotion, most teachers believe research achievements are twice as important as teaching practice (Knapper, 1990). The reason for this contradiction is the decision of promotion. Fairweather (1993) pointed out that teachers' rank and salary have a positive correlation with the research products and have a negative correlation with teaching products (presented by the curriculum numbers and number of students). Overall, the promotion system in university prefers research more. The reward system of universities will influence teachers' specific working interests. Carol (1992) used 5,450 teachers of 306 two-year and four-year colleges as samples. She adopted internal interest and external reward, working pattern and personnel background factors as a concept model and tried to examine how promotion rewards influenced senior teachers' interest in teaching and research. The results showed that even when teachers become tenured, teachers' perception of what duties are rewarded by the promotion system is still influenced by their own interest in professional duties. When teachers found that research was useful to pass promotion requirements, they preferred research over teaching. Similarly, when teachers found that teaching was useful in promotion, they chose teaching tasks first. Professors' working interest is connected closely to the duty that their institutions emphasize. Fairweather (1992) used 8,383 
teachers at 424 universities in the United States as samples and tried to examine the relationship of duty and reward and the role of teaching in the teacher reward system. The results found that teaching and reward have a negative correlation and research and reward have a positive correlation. This situation exists in different types of higher education institutions. Du (2002) found that the university reward system has a correlation with teachers' working time arrangement, but the correlation is not strong. Although teachers thought of research work as their personal interest, an achievement to aspire to, useful for promotion, and having a higher social position and salary reward, most teachers still thought teaching was the most important duty, because teaching is the natural duty of teachers. Fewer teachers who are research-oriented have surrendered to the need for promotion and the research pressure from the university environment which forces them spend more energy on research ( $\mathrm{Du}, 2002)$. The rewards that teachers get included external rewards (salary) and internal rewards (job satisfaction). Higher education lacks external and internal rewards for teaching, so teachers lack motivation to spend time on teaching and lack the need to improve teaching methods and curricula. They do not try to work hard on effective teaching and improve teaching methods. If we want to improve teaching quality and teachers' teaching emphasis, higher education institutions need to use student learning outcomes as goals and try to reward and evaluate teaching to motivate universities and teachers to do teaching training and involvement in teaching professional development activities (Knapper, 1997).

Based on the literature review of research about the priority between research and teaching, the current study aims to explore whether the phenomenon that research has been valued over teaching exists in Taiwan's academia, and the reasons causing and influencing this phenomenon. To achieve these purposes, the current study examined promotion and evaluation criteria of universities, analyzed university teachers' work time arrangements, and collected teachers' opinions about the priority of research, teaching, and service tasks.

\section{Methodology}

The purpose of this study is to explore whether the phenomenon that research has been valued over teaching exists in Taiwan's academia, the reason causing this phenomenon, and the influences that cause teachers to value research over teaching. To achieve these purposes, the study applied document analysis, questionnaire inquiry data analysis, and interview as the research methods. The process used to run the document analysis, questionnaire inquiry, and interview is described below:

\section{Document analysis}

The study used document analysis to analyze the requirements of universities for their teachers in the duties of research, teaching and service. The samples and process are described below.

\section{Sample}

In order to collect the range of differing requirements of the reward system in different areas, our study analyzed twelve different universities' requirements. These twelve universities' areas of specialty include five general studies universities, two education universities, two medical 
universities, one vocational studies university, and one arts university. Ten of them are public universities and two of them are private universities.

\section{Process}

The study collected and analyzed the documents for teacher promotion and teacher evaluation from these twelve different universities. The documents collected by the study included the laws and regulations used for the whole university and each college in every university. The documents were collected from the websites of the personnel department, the office of academic affairs, and each college in every university. In the study, we downloaded the newest version of the laws and regulation whenever possible. If the promotion or evaluation regulations were not available on a university's website, we called the office and asked them to provide the documents for us. After all the documents were compiled, a statistic list was made to compare the evaluation criteria and the proportion of the weight of teaching, research, and administrative service in each college in every university.

\section{Questionnaire inquiry data analysis}

The study used questionnaire inquiry data analysis to analyze teachers' time involved on research, teaching and service duties. The samples and process are described below.

\section{Sample}

The study used empirical data from the Taiwan Higher Education Database. The Ministry of Education in Taiwan authorized the Center for Higher Education of Chi-Hua University to investigate the working conditions of teachers in higher education in 2004. The data includes 12,747 samples from 156 universities. The questionnaire included seven parts: work and life conditions, teaching strategies and student assessments, satisfaction of working environment, opinions about students, personal information, and other.

\section{Process}

The data was obtained from the Survey Research Data Archive of the Academia Sinica. The study used the data of the working hours every week in different events in the first part (work and life condition) and used the version 18 SPSS statistic software to run frequency, MANOVA, regression, and correlation statistics.

\section{Interview}

The study used interview to collect teachers' opinions of task priority on research, teaching and service duties. The samples and process are described below.

\section{Sample}

The study interviewed twenty professors who have different areas of study and work in different types of universities. The backgrounds of these teacher samples include: five professors, 
five assistant professors, and ten associate professors in the sample group. Nine served in public universities and eleven served in private universities. Their study areas include business, education, engineering, urban planning, computing, transport services, mathematics and statistics, and life science.

\section{Process}

These teachers were asked to give the order of their priorities and time spent on the three tasks of teaching, research, and service. The study collected, combined, and analyzed their opinions and the order of the three tasks. The data was collected over four weeks in April, 2014.

\section{Findings}

The results of the study include three parts. The first part is the result of document analysis, which is about the requirements of promotion and evaluation systems of the three duties. The second part is the result of the statistical analysis of Taiwan Higher Education Database, which is about teachers' time arrangement of teaching, research, and service tasks. The third part is the result of interview, which is about teachers' opinions of the priority of teaching, research and service tasks.

\section{Document analysis: The requirements of promotion and evaluation systems of three duties The analysis of the promotion system}

The results show that universities in Taiwan design their promotion system based on the rules set by the Ministry of Education. Originally, the promotion system focused on research products most. The Ministry of Education tried to redirect this situation by asking every university in Taiwan to set a rule for teaching and service assessment to make teachers focus not only on research but also on teaching and service. Now almost every promotion system in universities in Taiwan includes the three tasks of research, teaching, and service. The proportion is about seventy percent which account for research, and teaching and service combined which account for thirty percent, but every university has the right to adjust the percentage.

The procedure of promotion is not the same among universities, although they all have similar principles. All universities have set the minimum standard for teaching, research, and service work products. Teachers who apply for promotion need to pass the minimum standard first, then can proceed to the promotion procedure. Passing the minimum standard of teaching and service is a prerequisite for research examination by outside reviewers, but the requirements of teaching and service are not difficult and teachers can always pass if they have done their teaching work, which is required by the university. Moreover, the score for teaching and service is given by the department, not outside reviewers, so the scores of teaching and service are usually very high and easy to get. Teachers emphasize the value of results of outside research review more than inside teaching and service examination results.

Based on the statistic results, the twelve sample universities all set orders or scores among articles which were published in different type of journals. The ranking order among universities is similar. The SSCI, SCI, and AHCI journals get the highest scores, then the TSSCI journals, then ordinary journals which include a review process, then books, and finally conference papers. Based 
on the journals' ranking order, five sample universities require teachers to achieve a research score which is accumulated by scores representing articles he or she published in different types of journals in order to get promoted. Of the twelve universities, eleven require a basic number of published articles as the prerequisite to apply for promotion. Seven of them require the representative work of teachers to be published in outstanding journals which are included in the SSCI, SCI, EI, AHCI, or TSSCI database. Four universities require a number of research projects which are funded by the National Science Council or another government organization as the prerequisite to apply for promotion. The statistic results are shown in Table 1. We can see that the journal ranking order has already become the common evaluation standard for research products. Teachers are all forced to pursue this standard and try to get their articles published in the journals which are included in the SSCI, SCI, EI, AHCI, or TSSCI database.

Table 1

The statistic of research promotion requirements

\begin{tabular}{l|c|}
\hline The promotion requirement of research & $\begin{array}{l}\text { The number of universities } \\
\text { which use this requirement }\end{array}$ \\
\hline $\begin{array}{l}\text { Set orders or scores among articles which are published in } \\
\text { different types of journals }\end{array}$ & 12 \\
\hline $\begin{array}{l}\text { Require a number of articles as a prerequisite to apply for } \\
\text { promotion }\end{array}$ & 7 \\
$\begin{array}{l}\text { Require the representative work of teachers to be } \\
\text { published in outstanding journals which are included in } \\
\text { the SSCI, SCI, EI, AHCI, or TSSCI database }\end{array}$ & 5 \\
\hline $\begin{array}{l}\text { Require teachers to achieve a research score which is } \\
\text { accumulated by scores representing articles they published } \\
\text { in different types of journals }\end{array}$ & \multicolumn{2}{|c|}{4} \\
\hline $\begin{array}{l}\text { Require a number of research projects which are funded } \\
\text { by the National Science Council or another government } \\
\text { organization as the prerequisites to apply for promotion }\end{array}$ &
\end{tabular}

Four of the five universities which set the promotion research minimum as publishing articles in outstanding journals are universities which got funding from the "Aim for the Top University Project." These types of universities have more strict promotion requirements, especially in the research part. They always authorize internal colleges to set their own promotion criteria to match the characteristics of specialty. In the regulations for promotion, the quality and quantity of research products are clearly set up. Many of them require the representative research products to be published in SSCI, SCI, AHCI, or TSSCI journals.

The goal of the "Aim for the Top University Project" is to support universities to get in the top one hundred in international university rank. Most of the evaluation criteria regarding world university rank are about the amount of research products and ratio of citations. Therefore, universities in Taiwan push their teachers to increase research products which are published in outstanding journals and to get high citation rates to become one of the top one hundred universities. Universities that have already obtained the funding set their promotion research requirements higher in order to maintain their vested interest and status. Universities that did not get the funding try to set their promotion research requirements higher in order to push their 
teachers to produce more and better research products to get funding.

On the other hand, the promotion criteria which are about the duties of teaching and service are easier. According to the results of document analysis, the teaching criteria include teaching hours, teaching evaluation results, number of graduate students, etc. The service criteria include the number of times teachers serve as committee members in committees at department, college, and school levels, as well as service such as speeches or consulting that teachers provide inside or outside the university. They are much easier to achieve than the research criteria. The result of teaching and service only account for thirty percent, or the minimum for promotion.

\section{Data analysis: The statistical analysis of teachers' time arrangement of teaching, research and service tasks}

The study combined tasks that belong to teaching, research, and service based on the results of factor analysis. We found that every week, teachers spent the most time on teaching, then on research, and finally on service (see Table 2). Although teachers spend a lot of time on research, there is still a lot of work in the duties of teaching and service: not only the time they spend teaching in class, but the time they spend on preparing courses, advising students, correcting assignments, attending meetings, giving speeches, and providing service. Even the time teachers spend on research is not only doing their own research but directing thesis projects and reviewing papers.

Table 2

Working hours per week for the three duties

\begin{tabular}{|c|c|c|c|}
\hline Duty & Teaching & Research & Service \\
\hline Rank & 3.16 & 2.75 & 2.12 \\
\hline
\end{tabular}

Note. Rank1: 0 (hour/week); Rank2: 1-5 (hour/week); Rank3: 6-10 (hour/week); Rank4: 11-15 (hour/week); Rank5: 16-20 (hour/week); Rank6: 21-25 (hour/week); Rank7: >26 (hour/week).

\section{The difference based on teachers' backgrounds}

The time teachers spent on different duties is different among the members of the sample group based on gender, ranking, university types, and whether teachers served in administrative positions or acted as advisors.

\section{Gender}

According to the results, female teachers spent more time on teaching duties (female: average 11.3 hours per week; male: average 10.6 hours per week) and male teachers spent more time on research (female: average 7.4 hours per week; male: average 9.0 hours per week) and service duties (female: average 5.1 hours per week; male: average 5.9 hours per week).

\section{Teacher ranking}

Teachers with different rankings have different time arrangements for their work. The statistic results showed that lecturers and assistant professors spent more time on teaching duties 
Chen, C.Y.

than higher ranking professors. Professors spent more time on research and service than associate professors and assistant professors.

Table 3

Working hours per week spent on three duties based on different teacher ranking.

\begin{tabular}{|l|l|l|}
\hline Duty & $F$ & Comparison \\
\hline Teaching & $38.592 * * *$ & $\begin{array}{l}\text { Lecturer and Assistant professor }> \\
\text { Associate professor }>\text { Professor }\end{array}$ \\
\hline Research & $648.201 * * *$ & $\begin{array}{l}\text { Professor }> \\
\text { Associate professor and Assistant professor } \\
>\text { Lecturer }\end{array}$ \\
\hline Service & $61.436 * * *$ & $\begin{array}{l}\text { Professor }>\text { Associate professor } \\
>\text { Lecturer }>\text { Assistant professor }\end{array}$ \\
\hline Note. $* * p<.01 . * * * p<.001$.
\end{tabular}

\section{Serving in administrative positions or acting as advisors}

If teachers served in administrative positions inside the university, they spent different amounts of time on their work than other teachers who did not serve in administrative positions. The statistic results showed that professors serving in administrative positions spent more time on service duties (average 12.3 hours per week) and less time on teaching duties (10.7 hours per week) and research duties (average 8.1 hours per week) than teachers who were not serving in administrative positions (average 7.8 hours on service duties, 11.1 hours on teaching duties and 9.0 hours on research duties). Being an advisor also influenced the time spent on work. Teachers who took advisory tasks spent more time on teaching (average 11.5 hours per week) and research (average 9.0 hours per week) and less time on service (average 5.3 hours per week) than teachers who did not act as advisors (average 9.0 hours on teaching duties, 8.1 hours on research duties and 6.1 hours on service duties).

\section{University types}

There are obvious differences in work time among teachers who serve in different types of universities. The comparison statistics results showed that teachers who serve in private universities (both vocational and general universities) spent more time on teaching duties than teachers who serve in public universities. Teachers who serve in public universities spent more time on research than teachers who served in private general universities and public vocational universities, and teachers who served in private vocational universities spent less time on research duties. Teachers who served in vocational universities (both public and private universities) spent more time on service than teachers who served in general universities (both public and private universities). 
Chen, C.Y.

Table 4

Working hours per week spent on the three tasks based on different university types

\begin{tabular}{|l|l|l|}
\hline Duty & $F$ & Comparison \\
\hline Teaching & $10.879 * * *$ & $\begin{array}{l}\text { Private vocational university and Private general university } \\
>\text { Public general university }\end{array}$ \\
\hline Research & $414.596 * * *$ & $\begin{array}{l}\text { Public general university } \\
>\text { Private general university and Public vocational university } \\
>\text { Private vocational university }\end{array}$ \\
\hline Service & $23.358^{* * *}$ & $\begin{array}{l}\text { Private vocational university and Public vocational university } \\
>\text { Public general university and Private general university }\end{array}$ \\
\hline
\end{tabular}

Note. $* * p<.01 . * * * p<.001$.

\section{Regression}

The results of regression show that the amount of time spent on research influences the time teachers spend on teaching. When teachers spend more time on research, they will also spend more time on teaching. Moreover, the time teachers spend on research will influence the time teachers spend on teaching and it can explain an effectiveness rate of $28.2 \%$. The time teachers spend on service also can influence the time teachers spend on teaching but has less influence than research. It can explain an effectiveness rate of $7.8 \%$. The relationship between research and teaching is shown in the figure below.

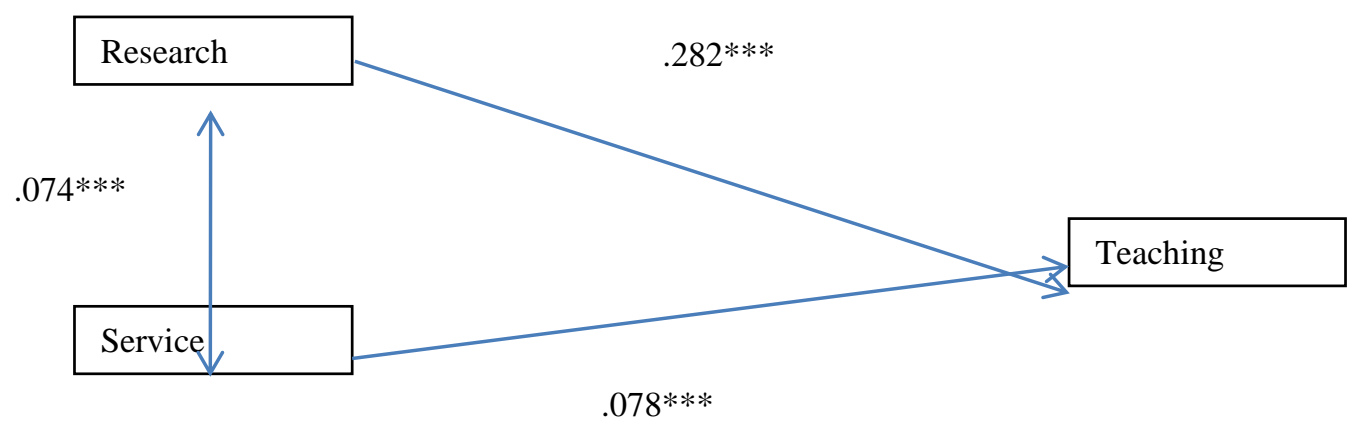

Figure 1. Regression among three duties

Note. $* * p<.01 . * * * p<.001$.

\section{Interview analysis: Teachers' opinions of the priority of teaching, research, and service tasks}

The results show that among the three duties of research, teaching, and service, teachers emphasized research as the most important task, and then teaching and finally service. As for the most important duty, among these twenty professors, there were twelve teachers $(60 \%)$ who felt 
research was the most important duty, eight teachers (40\%) who thought teaching was the most important duty, and none (0\%) who thought service was the most important duty. As for the second most important duty, among these twenty professors, eight teachers (40\%) thought it was research, twelve teachers $(60 \%)$ thought it was teaching and none $(0 \%)$ thought it was service. As for the third most important duty, none of the professors $(0 \%)$ pointed to research; none $(0 \%)$ point to teaching, and twenty of them (100\%) point to service.

When we asked the teachers to give the order of the priority of time spent on these three duties, most teachers mentioned teaching as the first priority as far as time spent. Eleven of them $(55 \%)$ thought teaching was the first priority, nine of them $(45 \%)$ thought research was the first priority, and none of them $(0 \%)$ thought service was the first priority. As far as time spent on the second priority, nine of them (45\%) thought they spent the most time on teaching, seven of them (35\%) thought they spent most time on research, and four of them (20\%) thought they spent the most time on service. As for the last priority, four of them $(20 \%)$ thought it was research, none of them $(0 \%)$ thought it was teaching, and sixteen of them $(80 \%)$ thought it was service.

Table 5

Teachers' order of the importance and the priority of time spent on three duties.

\begin{tabular}{|l|l|l|l|l|l|l|l|l|l|l|l|l|}
\hline & & \multicolumn{3}{l|}{ Research } & \multicolumn{3}{l|}{ Teaching } & \multicolumn{3}{l|}{ Service } \\
\hline \multirow{2}{*}{$\begin{array}{l}\text { The order of importance of three } \\
\text { duties }\end{array}$} & Rank & $1^{\text {st }}$ & $2^{\text {nd }}$ & $3^{\text {rd }}$ & $1^{\text {st }}$ & $2^{\text {nd }}$ & $3^{\text {rd }}$ & $1^{\text {st }}$ & $2^{\text {nd }}$ & $3^{\text {rd }}$ \\
\cline { 2 - 12 } & $\begin{array}{l}\text { Teacher } \\
\text { Numbers }\end{array}$ & 12 & 8 & 0 & 8 & 12 & 0 & 0 & 0 & 20 \\
\hline \multirow{2}{*}{ The priority of time spent } & Rank & $1^{\text {st }}$ & $2^{\text {nd }}$ & $3^{\text {rd }}$ & $1^{\text {st }}$ & $2^{\text {nd }}$ & $3^{\text {rd }}$ & $1^{\text {st }}$ & $2^{\text {nd }}$ & $3^{\text {rd }}$ \\
\cline { 2 - 11 } & $\begin{array}{l}\text { Teacher } \\
\text { Numbers }\end{array}$ & 9 & 7 & 4 & 11 & 9 & 0 & 0 & 4 & 16 \\
\hline
\end{tabular}

It is interesting that although the majority of teachers think of research as the most important duty, there was still twenty percent of teachers who thought it was the least important. Although teaching has been thought of as the second most important duty after research, it was the task that the most teachers gave as the first priority as far as time spent and no one thought it was the last priority. When these sample teachers were asked what the most important responsibility of university teachers was, they all had the same answer that providing good teaching and good care to students was the most important thing. The reason that they emphasized research more than teaching is because of the requirements of promotion, and because sometimes the results of research were good for teaching.

\section{Discussion}

The results show that the promotion and evaluation system emphasizes research over teaching and service. These results match previous research results (Fairweather, 1992, 1993; Knapper, 1990). Teachers' research achievement is judged based on their articles published in different types of journals. The SSCI, SCI, and AHCI journals get the highest scores, then the TSSCI journals, then ordinary journals which include a review process, then books, and finally conference papers. Some universities also require teachers to obtain research project funding as the promotion criteria. Except for promotion requirements, teachers need to pass teacher evaluation 
every three to five years. The promotion and evaluation system emphasize research more.

The results also show that teachers spent the most time on teaching, then on research, and finally on service. The results match the previous research results (Commonwealth Magazine, 2012; Du, 2002; Seaberg, 1998). Different teachers' backgrounds have different time arrangements. Female, lower ranking (lecturers and assistant professors), private university and vocational university teachers spent more time on teaching tasks than male, higher ranking (associate professors and professors), public university, and general university teachers. On the contrary, the male, higher ranking, public university and general university teachers spent more time on research tasks than female, lower ranking, private university, and vocational university teachers. The time teachers spent on teaching and service had a positive correlation: teachers who spend more time on research will spend more time on teaching. Although the majority of teachers thought research was the most important duty, there was still twenty percent of teachers who thought it was least the important. Although teaching has been thought of as the second most important duty after research, most teachers spent time on it as their first priority and no one thought it was in the last priority place.

We can say that the system of promotion and evaluation emphasizes research more than teaching. Although teachers understand that they should have sufficient research products to be promoted and pass evaluation, they still spend a lot of time on teaching. When teachers spent more time on teaching, they will spend more time on research.

Although teacher evaluation and promotion are methods to encourage teachers to improve working quality and quantity, the design of these systems fall into the pattern of neoliberalism and academic capitalism. To increase the nation's competitiveness through better higher education, the government uses funding allotment as an attraction to encourage universities to become included in the top one hundred groups in the world university ranking. To expand the opportunity and ability to ascend to a higher rank in the world university ranking, universities use the criteria of teacher promotion and evaluation to force their teachers to increase research products and performance quality. This model controls through accountability, layer upon layer. In this model, the universities try to get more funding, and teachers try to publish more papers and get more research project funding to meet the accountability requirements but do not achieve the purpose of higher education. Getting funding or not influences the reputation, student recruitment, and management resources of universities. It seems students and parents lead the market choice, but actually the government controls the market through accountability.

The results show that all universities use the same research standard of requiring their teachers to produce SSCI, SCI, AHCI, or TSSCI papers. Universities that achieve the standard will create a more severe and strenuous standard. Universities that cannot reach the standard try to do more to compete with others. The workload has increased and teachers feel more pressure and anxiety in the process. A vicious cycle imperceptibly formed. To achieve research requirements is not an easy process. Compared to research scores, teaching scores and service scores are easy to obtain. Because of these promotion rules, we can imagine that teachers devote more time and energy to research than to teaching and service.

Furthermore, even in the situation that teachers have heavy pressure to do research, teachers spend at least as much time on teaching and service as on research. If this situation continues, the working time and pressures of teachers will increase endlessly, which is not good for higher education professional academic human capital of our country. Even the results of teaching evaluation which depend on student satisfaction are only a small proportion. Teachers who work hard to provide outstanding teaching only can earn one to five points more than teachers 
who just provide average teaching and put more energy into research work. This reason is another example of why teachers emphasize research more than teaching.

In the results of interviews, we found that teachers who think teaching is an important duty want to devote more time to it and gain the feeling of achievement from the process of teaching and interaction with students. We should try to increase the importance of teaching in higher education but not encourage teachers to agree with the concept that research is more important than teaching through the design of the reward system.

\section{Conclusion}

The academia in Taiwan exhibits the phenomenon that research is valued over teaching. The reasons causing the situation are due to the fact that the requirements of research criteria of evaluation and promotion, publishing in SSCI, SCI, AHCI, or TSSCI journals, and getting funding from government organizations have become teachers' common goals. Universities and teachers all try to use their professionalism as capital to gain financial support from the government. The academic capital formed gradually. However, both publishing in outstanding journals and getting research funding are difficult and quite competitive. This situation makes teachers fall into an endless vicious cycle. The workload becomes heavier and working pressures increase. Teachers try to put more time and energy into research but still need to maintain teaching and service work quality. Because the teaching criteria of promotion and evaluation are not hard to achieve and both the best teaching quality and merely average teaching quality get similar scores resulting in evaluation and promotion, some teachers focus more time and energy on research and ignore the needs of students. Although the research results of universities are useful to the international visibility of the nation's higher education, ignoring the encouragement and nurturing of professional ability and critical thinking ability of the next generation which needs more time to develop and cannot profit quickly is not beneficial in the long term. If we just narrow our view to get funding and pursue a top world university ranking without encouraging our teachers to involve themselves in the endeavor of teaching, or just think research will improve teaching but ignore teaching strategy, beliefs, and skills that teachers need when delivering professional knowledge, teachers in universities will only pursue better performance in research and will ignore the needs of students. Moreover, teaching effectiveness in Taiwanese universities will not improve or may even decrease in the future if emphasis on research and publications continues. This trend is detrimental to the development and advancement of professional personnel in our country. Based on the research results, our suggestions are to explore methods of evaluating teaching effectiveness and use them as the promotion criteria to increase the value of teaching in the promotion system. Moreover, higher education institutions should try to explore the possibility of and ways to implement a teaching track promotion system to allow teachers who see teaching as their main focus to get promotions through their abilities and achievements and not be restricted by promotion systems which focus on research products. This would encourage teachers to try their best to increase their teaching effectiveness, and this strategy would be a beneficial in any discipline.

\section{Acknowledgements}

Appreciation is extended to the Taiwan Ministry of Science and Technology for funding the research for this study under the project "A study of the phenomenon that research has priority 
Chen, C.Y.

over teaching and its influence on teaching professional development." Thanks also to Ms. Rebecca Miller for English writing advice and the assistance from my helpful research assistants.

\section{References}

Carol, C. (1992). Extrinsic rewards and intrinsic interest: The influence of tenure on faculty preference for teaching or research. ASHE Annual Meeting Paper, 37.

Chen, B. S. (2001). A study on the relationship of university faculty's promotion system, faculty's professional growth, and school development orientation. Journal of National Taipei Teachers College, 14, 163-208.

Chou, C. P., Wu, R. F., \& Hu, J. (2011). The impact of SSCI on Taiwan's academic evaluation in humanities and social sciences: A case study of NCCU. Journal of Comparative Education, 70, $31-56$.

Commonwealth (2012, October 3). Forty percent professors: The education system in Taiwan can't improve the quality of students. Retrieved from http://www.cw.com.tw/article /article. action $? \mathrm{id}=5043846 \&$ idSubChannel $=41$

Du, J. (2002). Teaching and research: The time involved of university professors. Journal of Pingtung Teachers College, 17, 135-174.

Dunkin, M. J. (1991). Determinants of academic career advancement at an Australian university. Higher Education Research and Development, 10, 115-131. doi: 10.1080/0729436910100201

Dunkin, M. J. (1994). Award winning university teachers' beliefs about teaching versus research. Higher Education Research and Development, 13, 85-91. doi: 10.1080/0729436940130108

Euster, G., \& Weinback, R. (1983). Rewards for faculty community service activities. Journal of Social Work Education, 19, 108-114. doi: 10.1080/00220612.1983.10778603

Euster, G., \& Weinback, R. (1994). Faculty rewards for community service activities: An update. Journal of Social Work Education, 30, 317-324.

Fairweather, J. S. (1992, October). Teaching and the faculty reward structure: Relationships between faculty activities and compensation. Paper presented at the Annual Meeting of the Association for the Study of Higher Education. Minneapolis, MN.

Fairweather, J. S. (1993). Academic values and faculty rewards. Review of Higher Education, 17, 43-68.

Fox, M. F. (1985). Publication, performance, and reward in science and scholarship. In J.C. Smart (Ed.). Higher education: Handbook of theory and research, 1. New York: Agathon Press. 
Chen, C.Y.

Gibb, O., \& Locke, B. (1989). Tenure and promotion in accredited graduate social work programs. Journal of Social Work Education, 25, 126-133.

Green, R. G. (2008). Tenure and promotion decisions: The relative importance of teaching, scholarship, and service. Journal of Social Work Education, 44(2). 117-127. doi:

10.5175/JSWE.2008.200700003

Knapper, C. K. (1990). Lifelong learning and university teaching. In I. Moses (Ed.). Higher Education in the late twentieth century: A festschrift for Ernest Roe. Kensington, New South Wales: Higher education research and development society of Australia.

Knapper, C. K. (1997). Rewards for teaching. New Directions for Teaching and learning. 72, 4152. doi: $10.1002 / \mathrm{tl} .7205$

Lin, J. Y., \& Yang, S.W. (2011).The study of human resource management of faculty in public universities in Taiwan. Journal of National Taichung University, 25(2),85-110.

Miller, D. (1978). Criteria for appointment, promotion, and retention of faculty in graduate social work programs. Journal of Social Work Education, 14(2), 74-81. doi:

10.1080/00220612.1978.10671503

Parker, J. (2008). Comparing research and teaching in university promotion criteria. Higher Education Quarterly, 62(3), 237-251. doi: 10.1111/j.1468-2273.2008.00393.x

Seaberg, J. R. (1998). Faculty reports of work-load: Results of a national study. Journal Social Work Education, 31, 7-19.

Seipel, M. O. (2003). Assessing publication for tenure. Journal Social Work Education, 39, 7988.

Sun, C. L. (2007). Accountability control or professional development? A dilemma of faculty evaluation in university. Journal of Educational Practice and Research, 20(2), 95-128.

The Higher Education Academy (2009). Reward and recognition in higher education institutional policies and their implementation. Retrieved from http://www.

heacademy.ac.uk/resources/detail/publications/Reward_and_Recognition_Resource2 Vardi, I. \& Quin, R. (2011). Promotion and the scholarship of teaching and learning. Higher Education Research and Development, 30(1), 39-49. doi: 10.1080/07294360.2011.536971

Walker, J. D., Baepler, P., \& Cohen, B. (2008). The scholarship of teaching and learning paradox: Results without rewards. College Teaching, 56(3), 183-189. doi:

10.3200/CTCH.56.3.183-190

Wei, M. H., \& Cheng, C. Y. (2006). The study on Taiwanese college students' perspectives of good college teachers based on teachers' research ability, instruction ability, and community service ability. Journal of National Hualien University of Education, 23, 103-130. 
Chen, C.Y.

Wray, M. L., Lowenthal, P.R., Bates, B., Switzer, T., \& Stevens, E. (2010). Examining faculty motivation to participate in faculty development. Retrieved from

http://www.slideshare.net/plowenthal/aera-2010-examining-faculty-motivation- for-professionaldevelopment

Wu, C. S. (2007). The crisis is an opportunity: The SWOT analysis of the situation of higher education. In National Taiwan University Press (Eds.). Mission and vision: Development plan for world class universities and research centers of excellence (pp. 74-105). Taipei: Office of Research and Development, National Taiwan University.

Young, P. (2006). Out of balance: Lectures' perceptions of differential status rewards in relation to teaching and research. Teaching in Higher Education, 11(2), 191-202. doi:

$10.1080 / 13562510500527727$ 